Research Article

\title{
Research of the Surrounding Rock Deformation Control Technology in Roadway under Multiple Excavations and Mining
}

\author{
Ming Su iD $^{1,2}$ and Xiaohui Gao ${ }^{3,1}{ }^{3,4}$ \\ ${ }^{1}$ School of Mining, Liaoning Technical University, Fuxin, Liaoning 123000, China \\ ${ }^{2}$ Datong Coal Mine Group Co., Ltd., Datong, Shanxi 037003, China \\ ${ }^{3}$ China University of Mining and Technology-Beijing, Beijing 100083, China \\ ${ }^{4}$ Cscec City Construction Development Co., Ltd., Beijing 100083, China \\ Correspondence should be addressed to Ming Su; smltusm@126.com
}

Received 29 December 2020; Revised 5 February 2021; Accepted 22 February 2021; Published 3 March 2021

Academic Editor: Junfei Zhang

Copyright ( $\odot 2021$ Ming Su and Xiaohui Gao. This is an open access article distributed under the Creative Commons Attribution License, which permits unrestricted use, distribution, and reproduction in any medium, provided the original work is properly cited.

\begin{abstract}
To effectively control the large surrounding rock deformation of the mining roadway under multiple excavations and mining in Wangcun coal mine, the field investigation, numerical simulation, field test, and monitoring were conducted, and the characteristics of stress and deformation evolution of the surrounding rock under the influence of multiple excavations and mining were analyzed; then the collaborative supporting technology of high prestressed bolt and short anchor cables was proposed in this study. The results show the following: (1) under the influence of multiple excavations and mining, the peak vertical stress of the typical air-return roadway reaches $23 \mathrm{MPa}$, and the deformation increases by about 2.8 times after the mining of adjacent panel. (2) The principle of the roadway support under the influence of multiple excavations and mining in Wangcun coal mine is determined; from the perspective of prestress, we can conclude that the active support of short anchor cables is better than that of long anchor cables. (3) Based on the results of the field monitoring, the bolt stress can be divided into four stages: the loss stage of prestress, the sudden-decrease stage of the roof periodic weighting, the decrease stage of advanced support, and the rapid-increase stage of strong disturbance. Due to the large anchorage range of anchor cables, there is no decrease stage of advanced support. After the application of prestress, the bolt stress of side bolts and top bolts decreases, and the reduction amplitude is up to $30 \mathrm{kN}$. (4) As the panel advances, the deformation of the surrounding roadway increases, and the growth rate is also increasing gradually. However, the final displacement of the roof, floor, and two sides is within $18 \mathrm{~mm}$. The bolt and anchor cables are not broken, and the control effect is good. The research results have a certain reference value for similar roadway control.
\end{abstract}

\section{Introduction}

The deformation and failure of the surrounding rock of mining roadways are affected by many factors, of which the excavation and mining is an important influencing factor [1]. Due to the superposition of the disturbance stress and the original rock stress under the action of multiple excavations and mining, the stress concentration of the roadway is extremely high, leading to the large deformation and failure of the surrounding rock [2-4].

In recent years, research on the deformation characteristics and control technology of the surrounding rock under the influence of multiple excavations and mining has been widely investigated. Xie et al. [5] studied the deformation characteristics of typical gob-side coal mines under the influence of repeated mining in Wangjialing coal mine, concluded that the surrounding rock presented asymmetric failure characteristics, and proposed the asymmetric control technology of high prestressed anchor cables truss $[6,7]$. Huang et al. [8] investigated the large deformation characteristics of the roadway with soft coal seams in the deep strong mining and proposed theoretical framework of the rheology of the surrounding rock and large deformation of the roadway caused by structural instability in the deep strong mining [9]. Jiang et al. [10] analyzed the comprehensive stress field characteristics of the original rock stress 
field, mining stress field, and support stress field of the typical mining roadway of the extra-thick coal seam in Majialiang coal mine under multiple excavations and mining [11].

Through the comprehensive numerical simulation, three-dimensional laser scanning technology and field measurement method, Guo et al. [12] analyzed the deformation characteristics of the roadway roof influenced by mining. Jia et al. [13] concluded that there was a large plastic failure depth in the coal side of the roadway during mining, and the maximum failure depth of the roadway slope was inclined to the roadway side [14-16]. On this basis, the high-extension combined bolt supporting technology was proposed [17]. According to the failure characteristics of the surrounding rock of the roadway passing through multiple rock strata under multiseam repeated mining, Sun et al. [18] put forward the nonuniform reinforcement technology for strengthening the support of weak structure parts. Based on the deformation characteristics of the surrounding rock in the roadway with seriously damaged section coal pillar under the influence of secondary mining, Qiao et al. [19] proposed the combined differential control technology of long anchor cables, high prestressed anchor cables, and steel belts.

Through the numerical simulation, Li et al. [20] concluded that the expansion pressure and the bursting deformation corresponding to rock failure in the nonuniform plastic zone led to the nonuniform and violent subsidence of the dynamic pressure roadway [21-23]. In case of severe subsidence, the scope of the plastic zone was determined by the magnitude of deviator stress, and the orientation was dominated by the direction of main stress [24-26]. The stress of the surrounding rock was improved by panel regulation, and the supporting technology of the subreinforcement was put forward. Xu et al. [27] and Lan et al. [28] proposed the comprehensive control of "high-strength bolt support + roof anchor cables channel steel composite structure + coal pillar side anchor cables reinforcement" according to the damage characteristics of coal roadway affected by severe fully mechanized mining [29-31]. Xu et al. [32] analyzed the characteristics of large deformation and failure of the roadway surrounding rock affected by strong dynamic pressure and proposed the technology of reconstructing bearing arch and adding high-prestressed anchor cables support [33-35]. In the above research, the deformation and control characteristics of mining roadways under the condition of severe mining influence have been explored $[36,37]$. However, the surrounding rock deformation characteristics of mining roadways under similar conditions of Wangcun coal mine have been rarely studied.

In this paper, the stress and deformation evolution characteristics of the surrounding rock under the influence of multiple excavations were mainly investigated, and the collaborative supporting technology of the high prestressed bolt and short anchor cables was put forward, and then the field tests were conducted to verify the effectiveness of the proposed supporting technology.

\section{General Situation of the Test Roadway}

2.1. Geological Conditions. The air-return roadway 5103, located in the east panel 8103 of Wangcun coal mine, was taken as the test roadway. The average buried depth of airreturn roadway 5103 was about $500.1 \mathrm{~m}$. The south of airreturn roadway 5103 was the panel 8101, the east was the three-panel lanes, and the west and north were all solid coal areas. The thickness of the coal was $3 \mathrm{~m}$, and fully mechanized mining was adopted. The air-return roadway 5103 was strongly influenced by the dynamic pressure of adjacent panel 8101 and panel 8103 . The design length was $2577 \mathrm{~m}$, and the mining was performed along the roof of no. 4 coal seam through breaking the floor. The direct roof and direct bottom were sandy mudstone; the main roof and the old floor were medium sandstone. The rock property characteristics of coal seam roof and floor are shown in Table 1 . The net width and clear height of the roadway were $5500 \mathrm{~mm}$ and $3200 \mathrm{~mm}$.

2.2. Original Support Scheme. As shown in Figure 1, the lefthand screw thread steel bolt without longitudinal reinforcement was used as the bolt. The specifications were as follows: (1) top bolt: $L=2.4 \mathrm{~m}, \phi 22 \mathrm{~mm}$, the parallel arrangement was adopted with the spacing and the row spacing of $1000 \mathrm{~mm}$ and $1150 \mathrm{~mm}$; (2) side anchor: $L=1.8 \mathrm{~m}, \phi 18 \mathrm{~mm}$, the spacing and the row spacing was $1000 \mathrm{~mm}$ and $1000 \mathrm{~mm}$; (3) anchor cables: $L=6.3 \mathrm{~m}, \phi$ $17.8 \mathrm{~mm}$, and the parallel arrangement was adopted; (4) resin anchoring agent: 1 CK2330 + 2 M2330 was placed in each hole of roof bolts, with anchoring force $\geq 125 \mathrm{kN}$ and pretightening force $\geq 220 \mathrm{~N} \cdot \mathrm{m} ; 2$ CK2360 + 1 M2330 were placed in each hole of anchor cables, with the pretightening force $\geq 100 \mathrm{kN}$; and 1 CK2330 + 1 M2330 was placed in each hole of two side bolts, with the anchoring force $\geq 85 \mathrm{kN}$.

2.3. Main Problems. The pretightening torque test of bolts in air-return roadway 5103 showed that the pretightening torque of most bolts was only $200 \mathrm{~N} \cdot \mathrm{m}$, and some of them were less than $180 \mathrm{~N} \cdot \mathrm{m}$. According to the research on the transformation of pretightening torque and pretightening force of bolts, the conversion efficiency of pretightening torque was less than 0.2 ; that is, the axial pretightening force of bolts was less than $40 \mathrm{kN}$. It indicated that there was a relatively low reinforcement effect on the surrounding rock of the roadway, and the core role of the bolt supporting has not been fully utilized.

\section{Stress and Deformation Evolution of the Surrounding Rock of the Roadway under Multiple Excavations and Mining}

Through the FLAC3D numerical software, the stress characteristics of the surrounding rock of air-return roadway 5103 during the whole service period were analyzed to facilitate the selection of a reasonable support scheme and parameter design optimization. The interval between airreturn roadway 5103 of panel 8103 and adjacent panel 8101 
TABLE 1: Rock property characteristics of coal seam roof and floor.

\begin{tabular}{|c|c|c|c|}
\hline Name of the roof and floor & Rock name & Thickness (m) & Features \\
\hline Main roof & $\begin{array}{l}\text { Medium } \\
\text { sandstone }\end{array}$ & $2.5-6.15$ & $\begin{array}{l}\text { Grayish white, calcareous cemented and mainly composed of quartz } \\
\text { feldspar }\end{array}$ \\
\hline Direct roof & Sandy mudstone & $1.5-4.32$ & Gray black, uniform bedding, massive structure \\
\hline Direct bottom & Sandy mudstone & $2.5-6.3$ & Gray black, flat fracture \\
\hline Main floor & $\begin{array}{l}\text { Medium } \\
\text { sandstone }\end{array}$ & $2.0-12$ & Gray white, calcareous cementation, general sorting \\
\hline
\end{tabular}

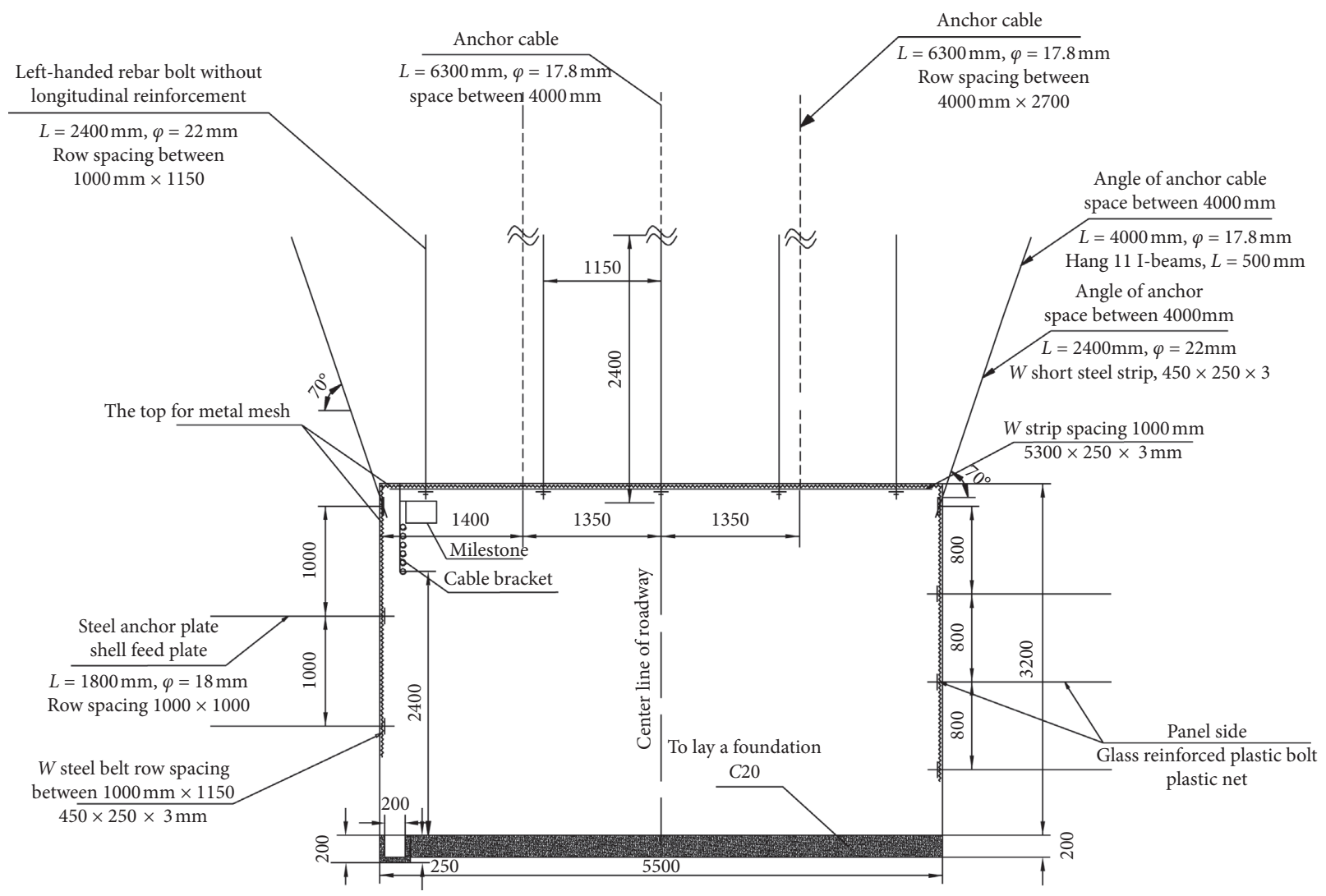

FIgURE 1: Original support scheme of air-return roadway 5103.

was a $25 \mathrm{~m}$ coal pillar. During the service period, air-return roadway 5103 was affected by multiple excavations and mining, including the excavation of air-return roadway 5103 , the excavation of the top air-return roadway of panel 8103, and the mining of adjacent panels 8101 and 8103. As a result, the complex stress change of the surrounding rock of the roadway has occurred, and the roof and coal pillar of the roadway bore large dynamic abutment pressure, leading to the strong stress changes and fluctuation for the air-return roadway 5103. The stability of air-return roadway 5103 was greatly affected under the action of multiple excavations stress.

3.1. Simulation Scheme. The strike length of panel 8101 was $1850 \mathrm{~m}$, while the length of air-return roadway 5103 was $2577 \mathrm{~m}$. Therefore, the section simulation of air-return roadway 5103 was carried out. Due to the limited space, the influence area of air-return roadway 5103 affected by the dynamic pressure of panel 8101 was mainly simulated.

Through the numerical simulation software, the calculation model was established to simulate the excavation of the air-return roadway 5103, the excavation of the top airreturn roadway of panel 8101, and the mining of panel 8101 . The stress change of the coal pillar, the stress, and displacement of the surrounding rock of the roadway under the above three conditions were comprehensively compared to obtain the basis for the subsequent support design.

\subsection{Stress Characteristics of the Surrounding Rock during the} Excavation of Air-Return Roadway 5103. In the excavation of air-return roadway 5103, the stress distribution of the surrounding rock and coal pillar was obtained, as shown in Figure 2. After the excavation of air-return roadway 5103, due to the influence of adjacent roadway 2101 , there was a 


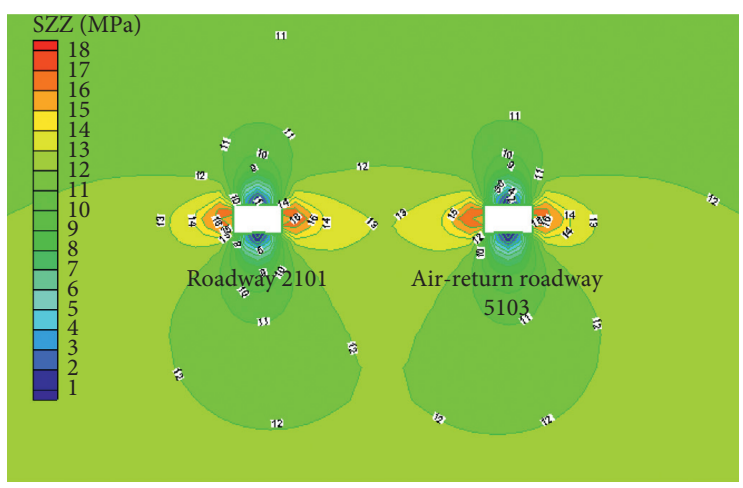

(a)

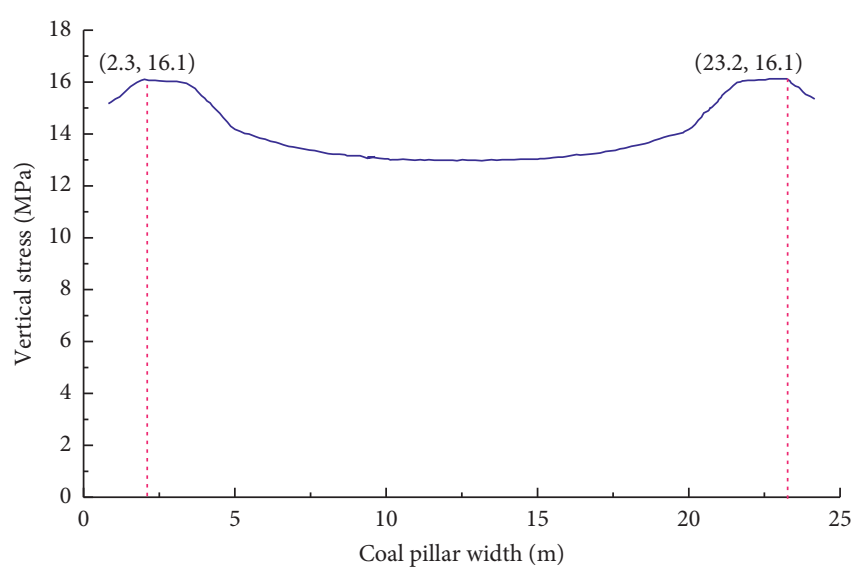

(b)

FIGURE 2: Vertical stress distribution of the surrounding rock and coal pillar during the excavation of air-return roadway 5103. (a) Vertical stress of the surrounding rock. (b) Vertical stress of the coal pillar.

certain superposition effect of vertical stress in two roadways, but the superposition effect of horizontal stress and displacement field was not obvious. After the excavation, the horizontal stress concentration area was distributed in the roof and floor of the roadway. Through comparative analysis, it can be seen that the peak value of the maximum vertical stress was about $16 \mathrm{MPa}$, and the peak value was located on the two sides of the roadway. The distance between the peak value of the vertical stress of the coal side and the coal wall was about $1.8 \mathrm{~m}$. The vertical stress distribution on the coal pillar was similar to that of the bimodal distribution. On the whole, the change of the vertical stress was small. It indicated that during the tunneling of the air-return roadway 5103, due to the small disturbance of the roadway during the excavation, the variation of the surrounding rock stress field had little influence on the roadway.

\subsection{Deformation Characteristics of the Surrounding Rock} during the Excavation of the Top Air-Return Roadway of Working Face 8103. After the excavation of air-return roadway 5103, the top air-return roadway of panel 8103 was arranged at $10 \mathrm{~m}$ away from the panel side of the roadway for gas drainage, which had a certain impact on the stability of the air-return roadway 5103. In particular, this top air-return roadway was arranged in the rock, and the blasting method was used for excavation; then the stability of the air-return roadway 5103 was affected. Therefore, the blasting can cause the coal wall spalling of air-return roadway 5103 during the tunnel excavation, which seriously affects the roadway stability.

Figure 3 shows the stress distribution of the surrounding rock and coal pillar during the excavation of the top airreturn roadway of panel 8103. It can be concluded that with the excavation of the top air-return roadway of panel 8103, the stress state of the surrounding rock of the roadway 5103 changes obviously. The superposition effect of the surrounding rock stress and the vertical stress of the side airreturn roadway 5103 is produced, leading to an increase in the peak value of vertical stress from 16.1 MPa to 17.0 MPa.

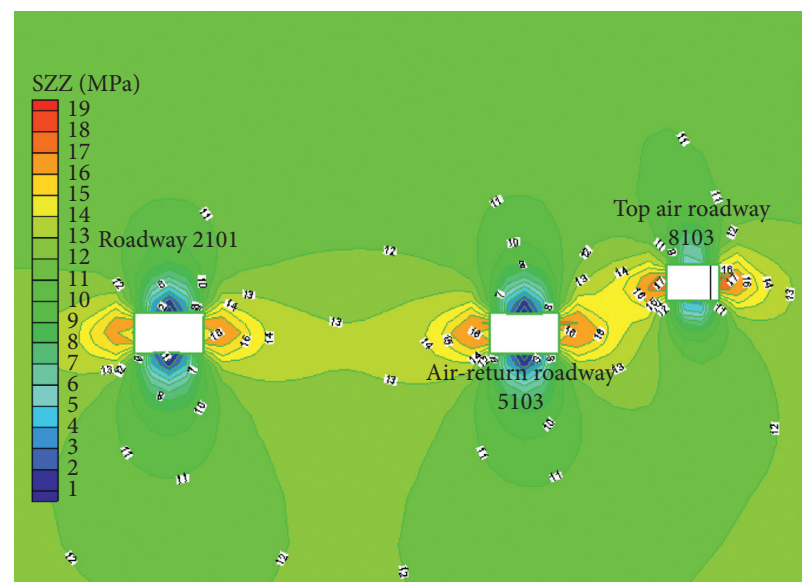

FIGURE 3: Stress distribution state of surrounding rock of 5103 return air roadway during the excavation of 8103 top return air roadway.

Besides, the peak area of vertical stress moves from the two sides to the upper right of the original roadway; the requirements of the roadway support are increased accordingly. Since the numerical calculation software cannot simulate the influence of rock blasting on the stability of airreturn roadway 5103, the real stress state of air-return roadway 5103 is worse than the calculation result. Thus, this factor should be further considered in the roadway support design.

\subsection{Stress and Deformation Characteristics of the Surrounding} Rock of Air-Return Roadway 5103 during Mining of Adjacent Panel 8101. After mining in panel 8101, the stress distribution of the surrounding rock and coal pillar around airreturn roadway 5103 is obtained, as shown in Figure 4.

As shown in Figure 4, after panel 8101 is mined, the stress and stress state inside the coal pillar, surrounding rock of the roadway, and the coal rock near the panel change greatly. The stress concentration inside the coal pillar and the coal 


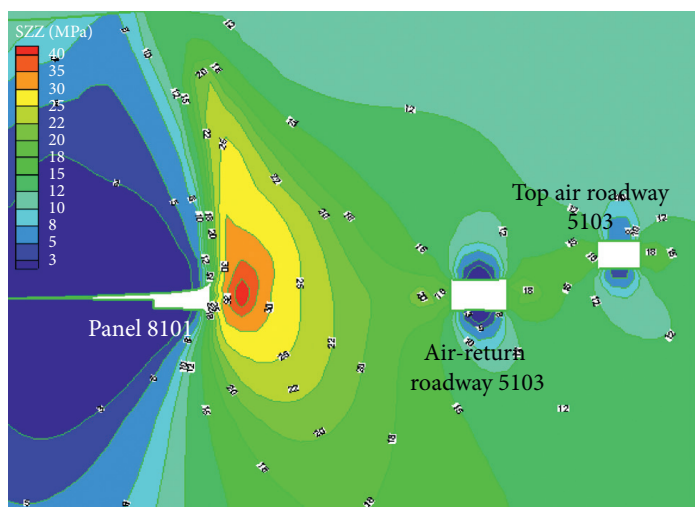

(a)

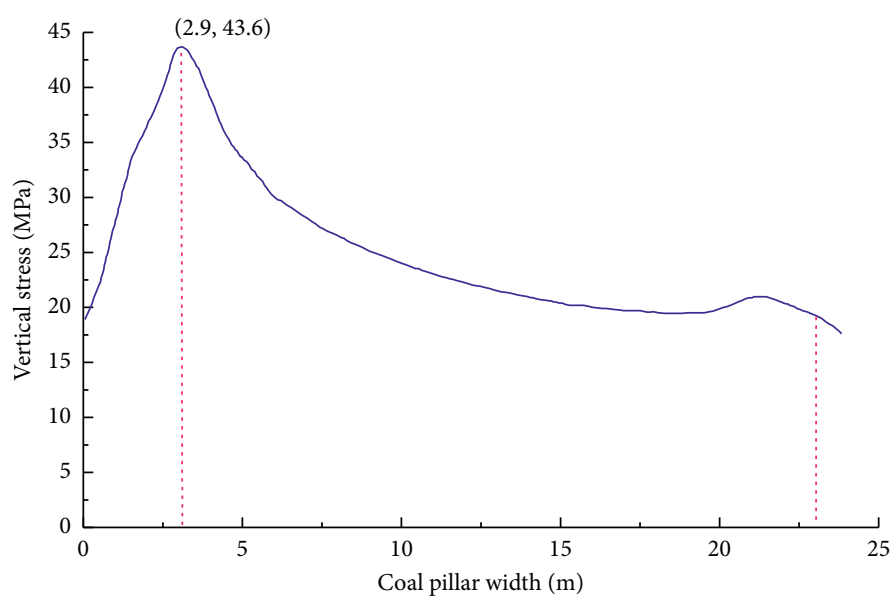

(b)

FIGURE 4: Vertical stress distribution of the surrounding rock and coal pillar in panel 8101. (a) Vertical stress of the surrounding rock. (b) Vertical stress of the coal pillar.

rock on both sides of the panel is obvious; with the change of the size of the protective coal pillar between panel 8103 and panel 8101, the stress and stress state of the surrounding rock in the coal pillar and roadway change significantly. When the size of the coal pillar is $25 \mathrm{~m}$, a great lateral abutment pressure is generated on the protective pillar of panel 8101 after the panel 8101 is mined. As a result, a large vertical stress concentration is formed on the coal pillar. The peak stress of the coal pillar appears at the panel side, and the peak value of vertical stress on the side of panel 8101 reaches 43.6 MPa, and the peak value of vertical stress on the side of air-return roadway 5103 reaches $21.33 \mathrm{MPa}$. It indicates that the concentration degree of lateral abutment pressure changes after mining on the panel due to the small size of the coal pillar at this time. It can be predicted that under such conditions, the roadway can be significantly affected by the dynamic pressure of panel mining, which is not conducive to the stability and maintenance of the roadway in the later stage.

In addition, the stress state of the surrounding rock and vertical stress of the coal pillar decreases obviously. Firstly, the double peak distribution state of vertical stress is changed, and the peak stress state of the surrounding rock is asymmetric. The overall vertical stress of the surrounding rock increases significantly, and the peak vertical stress of the coal pillar stress is $43.9 \mathrm{MPa}$, while that of air-return roadway 5103 is $23 \mathrm{MPa}$. It shows that the mining of panel 8101 has a great influence on the dynamic pressure of airreturn roadway 5103 at this time.

3.5. Deformation Variation Characteristics of the Roadway Surrounding Rock of 5103 Return Air Roadway under Multiple Excavations and Mining. The displacement of air-return roadway 5103 under multiple excavations and mining is obtained, as shown in Figure 5. In the excavation stage of air-return roadway 5103, $25 \mathrm{~m}$ coal pillar at the panel has little influence on the air-return roadway 5103. In the excavation stage, the overall deformation of air-return roadway 5103 is small, the maximum roof subsidence is $56.6 \mathrm{~mm}$, and the roadway floor heave is $88.2 \mathrm{~mm}$. Roadway deformation is mainly characterized by roof subsidence and floor heave, and the subsidence in the middle of the roof is similar to the bending deformation of simply supported beams under uniformly distributed load. The displacement of air-return roadway 5103 in the excavation stage of the top air-return roadway of panel 8101 shows that the excavation of the top air-return roadway of panel 8101 has a certain impact on air-return roadway 5103; the maximum roof subsidence increases from $56.6 \mathrm{~mm}$ to $59.6 \mathrm{~mm}$, and the roadway floor heave remains basically unchanged, always $88.2 \mathrm{~mm}$. It indicates that the excavation of the top air-return roadway of panel 8101 has a certain impact on air-return roadway 5103, and the stress of the surrounding rock and the deformation of the roadway increases, but the overall effect is not very significant. During the mining period of panel 8101, the air-return roadway 5103 is affected by the mining dynamic pressure of adjacent panel 8101; the vertical deformation distribution of 5103 is obtained. It indicates that the roof deformation of the roadway is relatively larger than that in the excavation stage. At this time, the maximum deformation of the roadway roof increases from $59.6 \mathrm{~mm}$ (in the excavation stage) to $166.9 \mathrm{~mm}$, which is 2.8 times larger than that before mining.

Through comprehensive analysis of the above calculation results, a comparison diagram of vertical stress of the surrounding rock and roof subsidence of air-return roadway 5103 under different mining conditions is formed, as shown in Figures 6 and 7.

As shown in Figures 6 and 7, the vertical stress around the roadway increases by $170.1 \%$ after mining at the adjacent panel of air-return roadway 5103. At this time, the maximum roof subsidence of the roadway is greatly increased, which increases by $194.5 \%$ during the original excavation period. It shows that the mining of adjacent panel 8101 leads to the significant influence of dynamic pressure, resulting in serious deformation of air-return roadway 5103. 


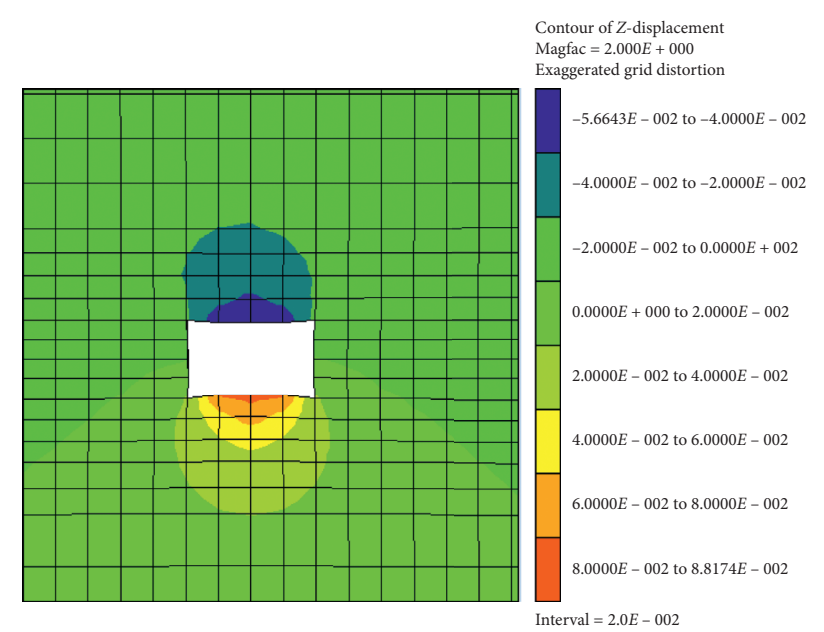

(a)

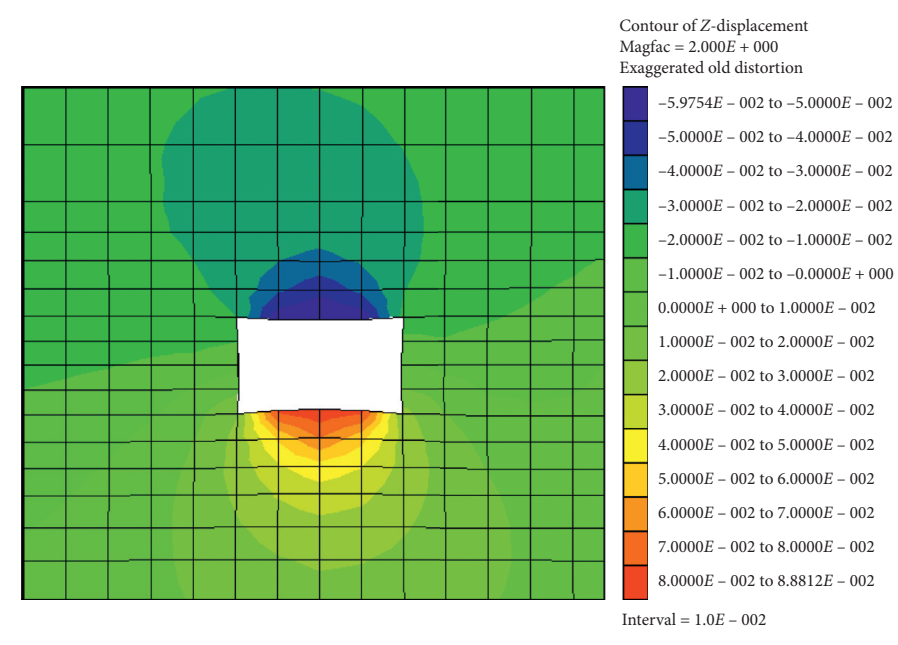

(b)

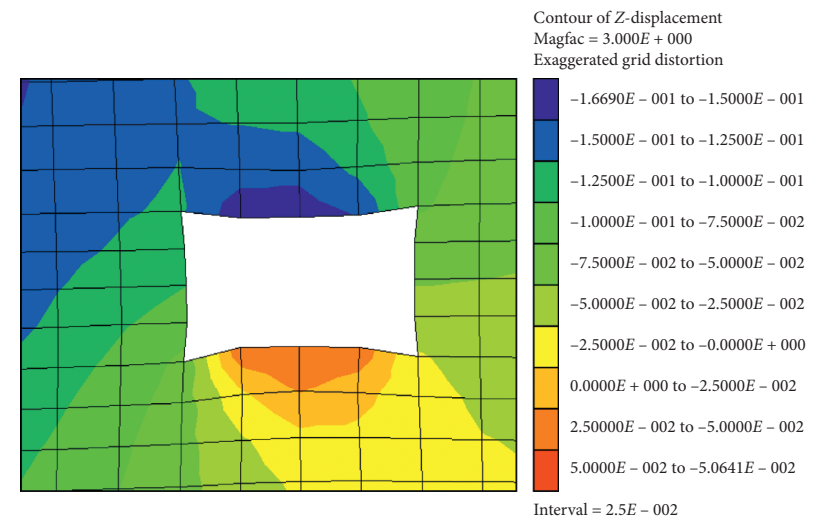

(c)

FIGURE 5: Deformation nephogram of air-return roadway 5103 under multiple excavations and mining conditions. (a) During the excavation of air-return roadway 5103. (b) During the excavation of the top air-return roadway of panel 8103. (c) During the mining of adjacent panel 8101 .

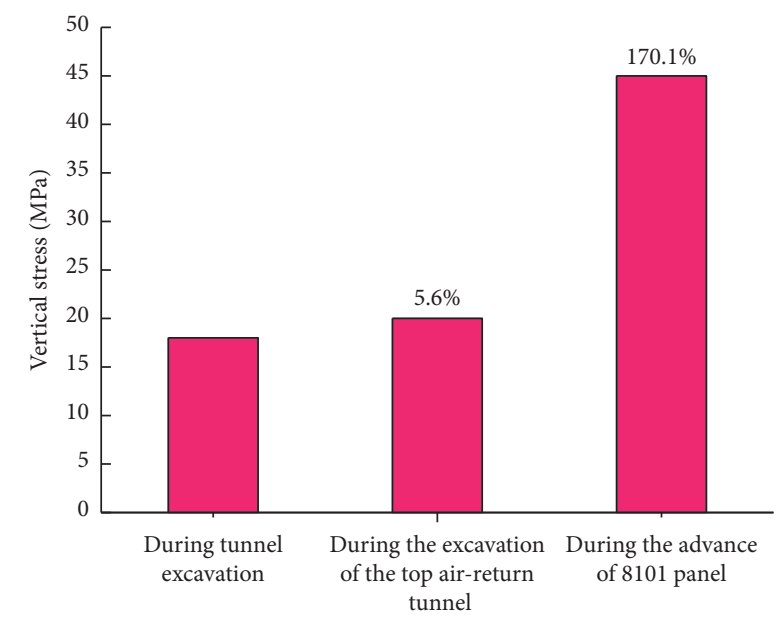

FIGURE 6: Comparison of peak vertical stress of the surrounding rock of air-return roadway 5103 in different mining stages.

In contrast, after the excavation of the top air-return roadway of panel 8101 , the peak value of vertical stress in the air-return roadway 5103 increased by $5.6 \%$. At this time, the

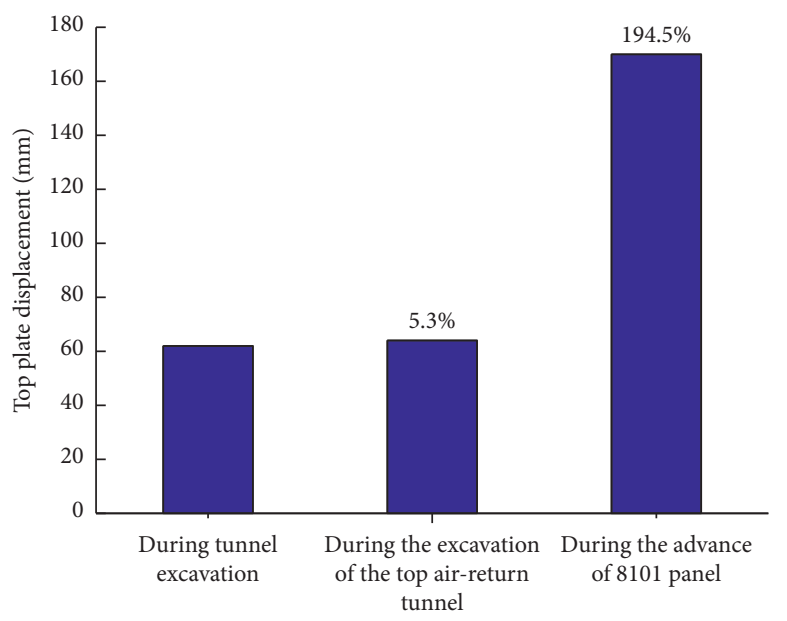

FIGURE 7: Comparison of roof subsidence of air-return roadway 5103 in different mining stages.

maximum roof subsidence of the roadway slightly increases, and it increases by about $5.3 \%$ during the original excavation period. It indicates that the excavation influence of the top 
air-return roadway of panel 8101 is small, and the deformation of air-return roadway 5103 is small.

\section{Efficient Collaborative Supporting Technology of High Prestressed Bolt and Short Anchor Cables}

In this paper, the geological conditions of the surrounding rock and the characteristics of stress and deformation evolution of the surrounding rock of air-return roadway 5103 under multiple excavations and mining were considered; then the collaborative supporting technology of the high prestressed bolt and short anchor cables was proposed for air-return roadway 5103.

4.1. Design Principle of the Roadway Support. According to the geological conditions of air-return roadway 5103 in Wangcun coal mine, the following design principles were proposed to give full play to the role of bolt support.

(1) The principle of one-time support: for the bolt support, one-time support is preferred to effectively control the deformation of the surrounding rock; the secondary or multiple support should be avoided.

(2) The principle of high prestress and prestress diffusion: prestress is the key factor in bolt support, which is the parameter to distinguish whether the bolt support is passive or active. Only the high prestressed bolt support is the real active support that can give full play to the role of bolt support.

(3) The principle of "three high and one low": "three high and one low" refers to the high strength, high rigidity, and high reliability and low support density. Under the condition of improving the strength and rigidity of the bolt and ensuring the reliability of the support system, the support density is reduced, the number of bolts per unit area is reduced, and the excavation speed is improved.

(4) The principle of critical support strength and stiffness: critical support strength and stiffness exist in the bolt support system. If the support strength and stiffness are lower than the critical value, the roadway will be in an unstable state for a long time, and the deformation and failure of the surrounding rock cannot be effectively controlled. Therefore, the strength and stiffness of the designed bolt support system should be greater than the critical value.

(5) The principle of mutual matching: the parameters and mechanical properties of bolt components should be matched, and the parameters and mechanical properties of bolt and anchor cables should be matched, so as to maximize the overall support effect of bolt support.

(6) The principle of operability: the bolt support design provided should be operable, which is conducive to the underground construction management and the improvement of excavation speed.
(7) Under the condition of ensuring the effect and safety of the roadway support, being feasible in technology and operable in construction, it is beneficial to reduce the comprehensive cost of the roadway support.

4.2. Comparison of Supporting Effects of Different Anchor Cable Lengths. As shown in Figure 8, the distribution of prestress field with different lengths of anchor cables is obtained under the same prestress $(200 \mathrm{kN})$ of anchor cables. The following can be seen:

(1) With the increase of the length of anchor cables, the range of the effective compressive stress zone gradually increases in the height direction, which indicates that the scope of the active support of anchor cables is expanding continuously. However, this change is not obvious in the width direction, and it has a decreasing trend with the increase of the length of anchor cables.

(2) With the increase of anchor cables length, the compressive stress in the middle and upper length of anchor cables decreases gradually. It indicates that the supporting effect of anchor cables on the middle and upper surrounding rock decreases continuously.

(3) With the increase of the length of anchor cables, the compressive stress of the middle surrounding rock between the two anchor cables gradually decreases. It indicates that the supporting effect of anchor cables on the surrounding rock between the two cables decreases gradually.

The analysis shows that under a certain prestress range, the longer the anchor cables, the less obvious the effect of prestressed anchor cables, and the worse the active support performance. Therefore, the following conclusions can be drawn:

(1) When the prestress is constant, the active support effect of short anchor cables is better than that of long anchor cables

(2) The longer the anchor cables are, the greater the prestressing force should be applied to fully realize the supporting function of anchor cables

(3) By increasing the prestress of anchor cables, the length of anchor cables can be reduced properly

To sum up, the comprehensive support effect is better when the length of anchor cables is in the range of $4 \mathrm{~m}-6 \mathrm{~m}$.

\subsection{New Support Scheme}

4.3.1. Roof Support. The bolt body was HRB400 left-hand nonlongitudinal rebar, with a diameter of $20 \mathrm{~mm}$ and a length of $2.0 \mathrm{~m}$, and the tail thread was M22. The length of the screw section at the end of the bolt was not less than $150 \mathrm{~mm}$. Resin anchorage agent was used to lengthen the anchorage length of bolts. The anchorage length was $1.3 \mathrm{~m}$, the spacing and the row spacing of bolts were $1200 \mathrm{~mm}$ and $1200 \mathrm{~mm}$, and the pretightening torque was $\geq 300 \mathrm{~N} \cdot \mathrm{m}$. The 


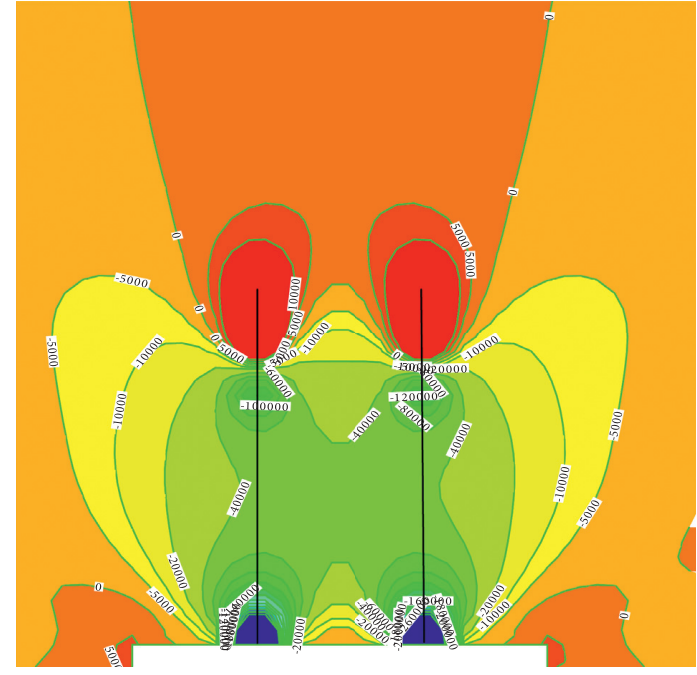

(a)

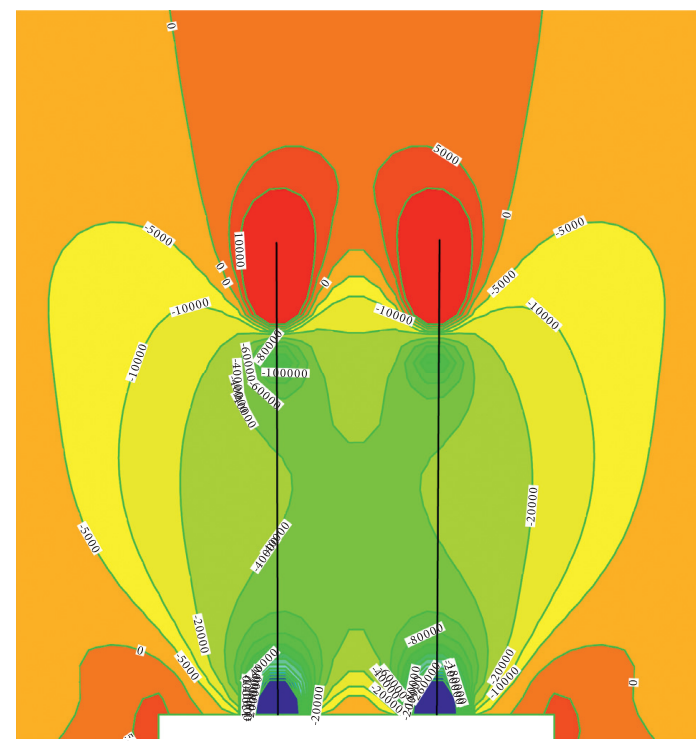

(c)

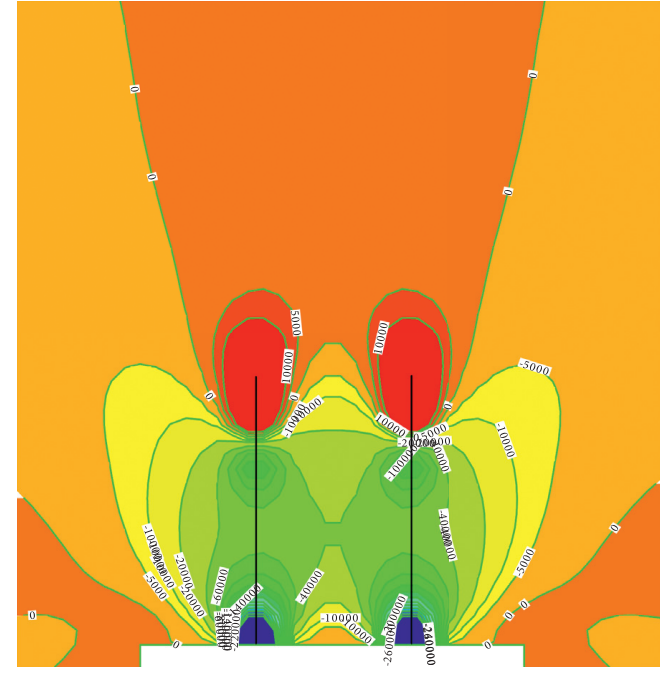

(b)

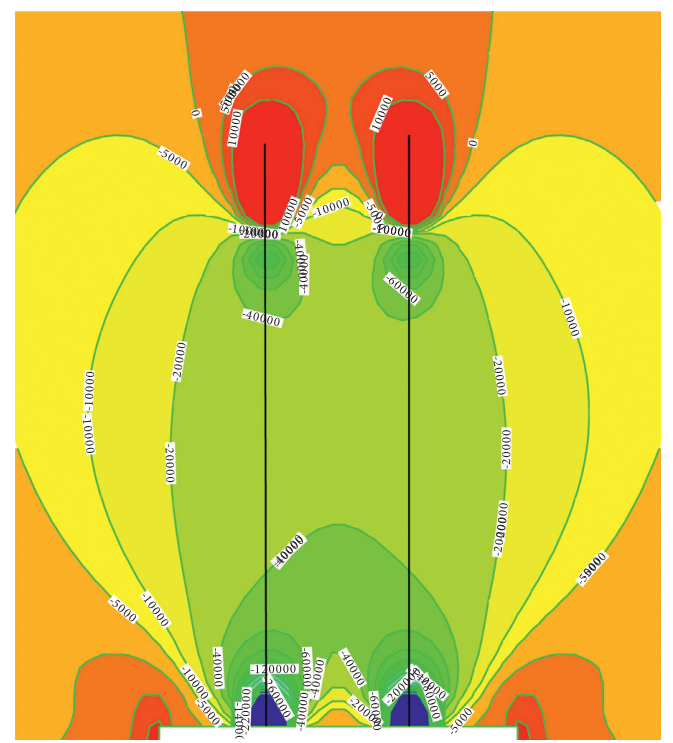

(d)

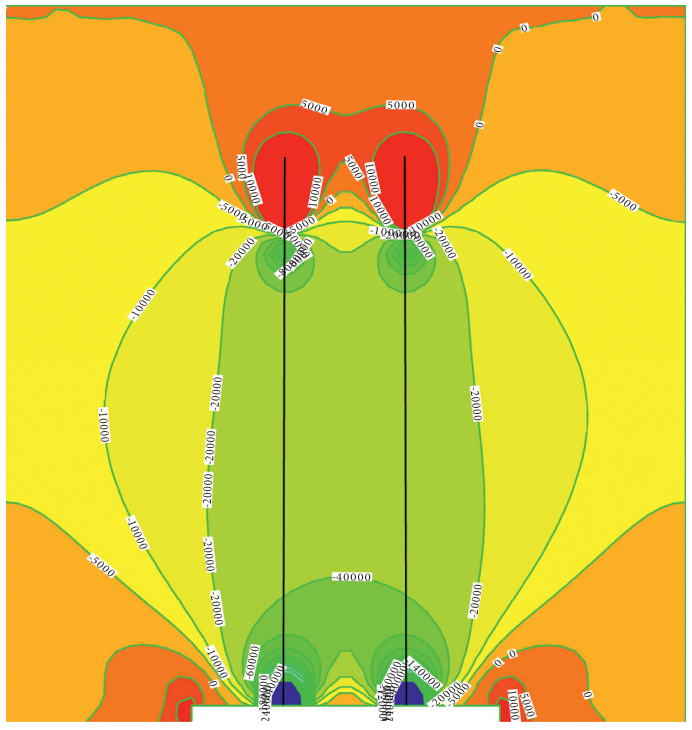

(e)

Figure 8: Stress distribution of different anchor cables lengths under the same prestress. (a) The length of anchor cables is $4 \mathrm{~m}$. (b) The length of anchor cables is $5 \mathrm{~m}$. (c) The length of anchor cables is $6 \mathrm{~m}$. (d) The length of anchor cables is $8 \mathrm{~m}$. (e) The length of anchor cables is $10 \mathrm{~m}$. 
top anchor cable materials were $\varphi 17.8 \mathrm{~mm}$ and $1 \times 7$ highstrength low-relaxation prestressed steel strand with a length of $5300 \mathrm{~mm}$ and the anchoring length of $1.6 \mathrm{~m}$. The "two, one-two, one spacing" arrangement was adopted with the spacing of $2400 \mathrm{~mm}$; two or one anchor cables were drilled in the middle of the roadway, and the spacing was $2400 \mathrm{~mm}$, vertical to the roof strata. The initial tension of anchor cables was $200 \mathrm{kN}$, and the loss of pretension shall not be less than $150 \mathrm{kN}$.

4.3.2. Side Wall Support of the Coal Pillar. The bolt body was HRB400 left-hand nonlongitudinal rebar, the diameter and the length of the top bolt diameter were $20 \mathrm{~mm}$ and $2.0 \mathrm{~m}$, the rod tail thread was M22, and the length of the bolt tail thread section was not less than $150 \mathrm{~mm}$. The anchoring length of the side anchor was $0.8 \mathrm{~m}$; the bolt row spacing was $1200 \mathrm{~mm}$, each row and each side has two anchors, and the spacing was $1400 \mathrm{~mm}$; the bolt pretightening torque was $\geq 300 \mathrm{~N} \cdot \mathrm{m}$. The material of side anchor cables was $\varphi 17.8 \mathrm{~mm}$, $1 \times 7$ strands of high-strength low-relaxation prestressed steel strand, with a length of $4300 \mathrm{~mm}$ and anchorage length of $1.3 \mathrm{~m}$. The "interval" arrangement was adopted, and one anchor cable was laid at $1 \mathrm{~m}$ above the roadway floor in two rows with the spacing of $2400 \mathrm{~mm}$, which was vertical to the coal wall; the initial tension of anchor cables was $200 \mathrm{kN}$, and the prestress loss shall not be less than $150 \mathrm{kN}$.

4.3.3. Panel Support. The bolt body was a $22 \mathrm{~mm}$ glass fiber reinforced plastic bolt, with a length of $2.0 \mathrm{~m}$; the bolt anchorage length was $0.8 \mathrm{~m}$; the bolt row spacing was $1200 \mathrm{~mm}$, each row and each side has three bolts, and the spacing was $900 \mathrm{~mm}$; the bolt pretightening torque was $\geq 50 \mathrm{~N} \cdot \mathrm{m}$. Figure 9 shows new support scheme for air-return roadway 5103 .

\section{Analysis of Ground Pressure Monitoring Results in the Test Area}

To master the influence of panel mining on the stability of the surrounding rock of the roadway and test the effect of the new support scheme, the stress monitoring of bolt and anchor cables and roadway deformation were carried out in the air-return roadway 5103. A test station was arranged around $627 \mathrm{~m}$ in front of the panel to monitor the stress of the supporting structure in the roadway and the deformation law of the surrounding rock during the periodic pressure, as shown in Figure 10(a). The layout of anchor cable dynamometer is shown in Figure 10(b). The specific monitoring scheme is as follows.

5.1. Stress Analysis of Bolt and Anchor Cables. Figures 11 and 12 show the stress curves of bolt and anchor cables, respectively.

(1) The bolt stress at different positions of roof and two sides are compared, and the overall law is consistent. After the bolt is applied with pretightening force, the stress decreases at
$110 \mathrm{~m}-115 \mathrm{~m}$ away from the panel, is stable at $70 \mathrm{~m}-100 \mathrm{~m}$ away from the panel, suddenly decreases near $70 \mathrm{~m}$ from the panel, is stable at $30 \mathrm{~m}-75 \mathrm{~m}$ away from the panel, then decreases at $20 \mathrm{~m}$ away from the panel, and then increases gradually. However, the overall range of variation is small, with the amplitude below $20 \mathrm{kN}$ (without considering the pretightening force). It can be explained that after the bolt is applied with prestress, due to the loss of prestress, the bolt stress is reduced, and then since the distance from the panel is far away from the panel and has not been affected by mining, the stress is relatively stable. At $70 \mathrm{~m}$ away from the panel, due to the periodic pressure of the roof of the panel, the main roof collapses, causing the surrounding rock rebound of the roadway, and the bolt stress suddenly decreases, and then due to the high prestressed bolt support energy effective control of the roadway surrounding rock deformation, bolt stress is still relatively stable, at a distance of $20 \mathrm{~m}$ from the panel layout of single hydraulic prop advance support, the initial support force of hydraulic prop makes the surrounding rock deformation converge, and bolt stress decreases; with the advance of the panel, roadway surrounding rock deformation gradually increases, and bolt stress also increases.

(2) By comparing the stress of bolts at different positions, it can be found that after the pretightening force is applied, both the stress of two side bolts and the top bolt decrease, and the reduction amplitude is as high as $30 \mathrm{kN}$. This is due to the loss of pretightening force. The loss value of roof bolts is lower than that of side bolts. This is because the roof is relatively flat and the pretightening force is high, while the surrounding rock of the two sides is uneven and the pretightening force is low. Therefore, the loss of pretightening force is closely related to the surface roughness of the surrounding rock and the value of pretightening force. The stress change of side bolt and roof bolt is not different, both within $5 \mathrm{kN}$. This is because the supporting technology of highstrength and high prestress bolt can improve the antideformation ability of the surrounding rock. However, the shaking of roof bolts is obvious at $70 \mathrm{~m}$ away from the panel, which is sensitive to the roof collapse under periodic weighting.

(3) The stress of the bolt near the coal pillar side is relatively stable, with the variation value of $1-2 \mathrm{kN}$. The bolt close to the panel side changes greatly; within $3-5 \mathrm{kN}$, the stress of the bolt at the side corner is relatively low. It indicates that the surrounding rock at the bottom corner has been broken, and the high stress is in the state of pressure relief after the transfer of high stress. The stress of the roof bolt close to the panel changes greatly compared with that of the middle and coal pillar side and is greatly affected 


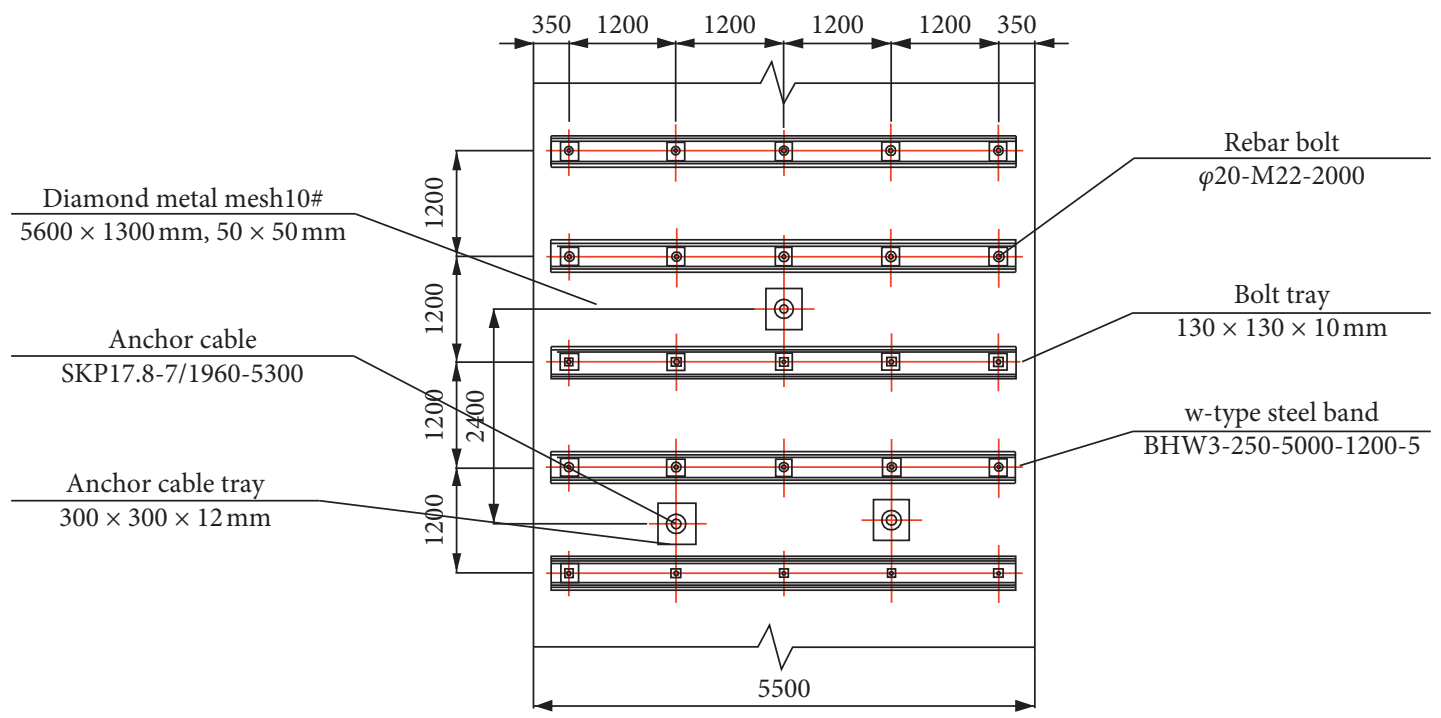

(a)

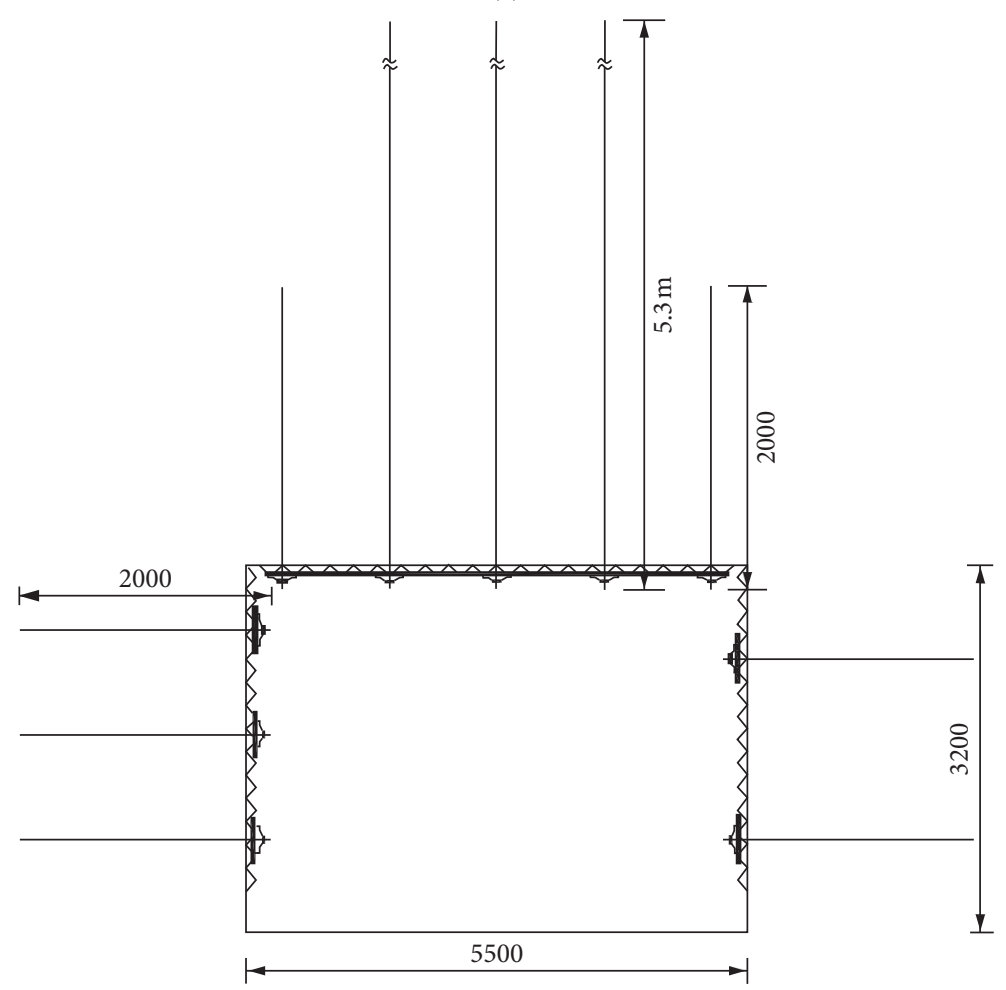

(b)

FIGURE 9: New support scheme for air-return roadway 5103.

by the mining of the panel. The change value is about $5 \mathrm{kN}$, and the difference of the pretightening force of the three roof bolts increases, which is related to the nonrelativity of the surrounding rock.

(4) The stress changes of roof anchor cables in different positions are the same. The stress decreases continuously at $70 \mathrm{~m}-90 \mathrm{~m}$ away from the panel; the shaking occurs at $70 \mathrm{~m}$, and the stress decreases rapidly and begins to increase. The stress of anchor cables at $20 \mathrm{~m}-70 \mathrm{~m}$ away from the panel is stable and increases gradually after $20 \mathrm{~m}$ away from the panel. This is because the anchor cables are damaged after the pretightening force is applied, and the stress of anchor cables decreases. Under periodic pressure at $70 \mathrm{~m}$ away from the panel, the main roof collapses and causes the roof rebound, which causes the sudden stress decrease of anchor cables. Within the range of $20 \mathrm{~m}-70 \mathrm{~m}$ from the panel, the influence of mining on the panel is small, and the stress is relatively stable. The range of $20 \mathrm{~m}$ away from the panel 


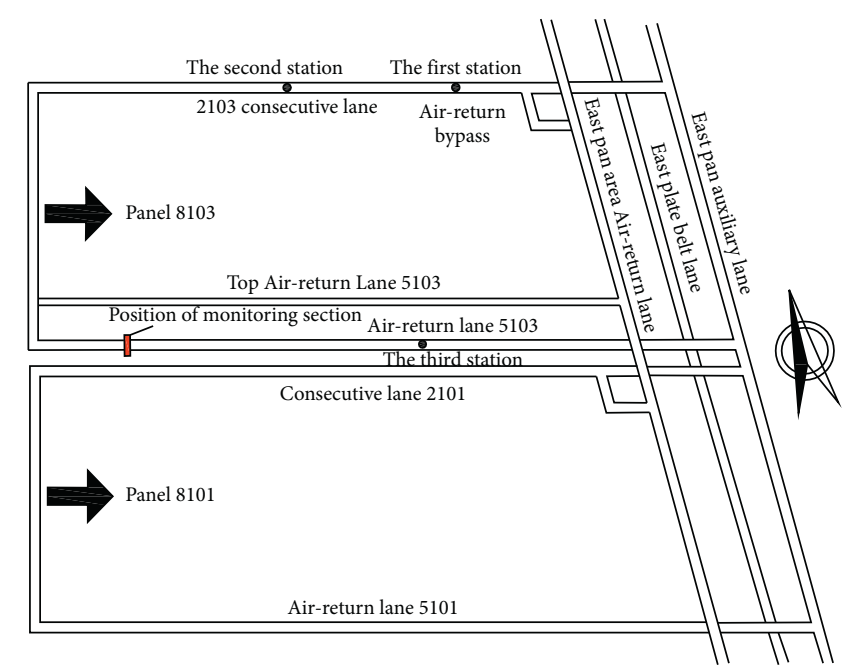

(a)

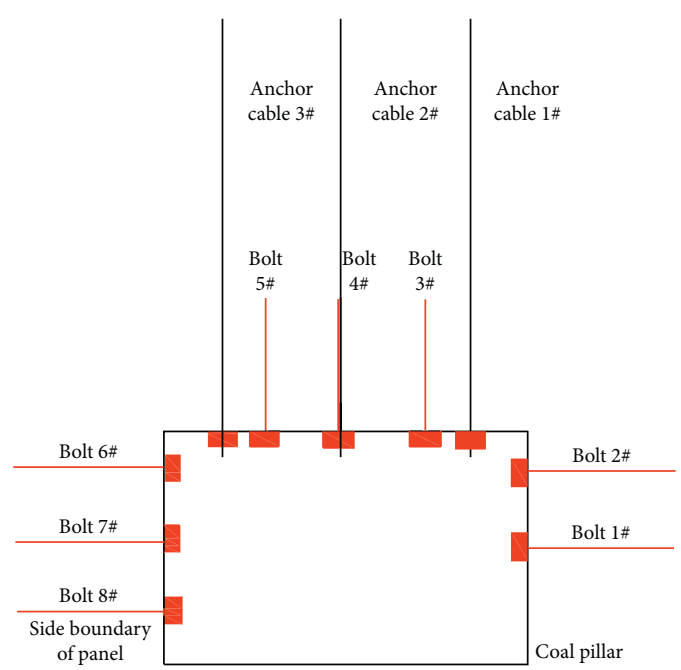

(b)

FIGURE 10: Layout of ground pressure monitoring points in air-return roadway 5103. (a) Layout of measuring points. (b) Arrangement of anchor cables dynamometer.
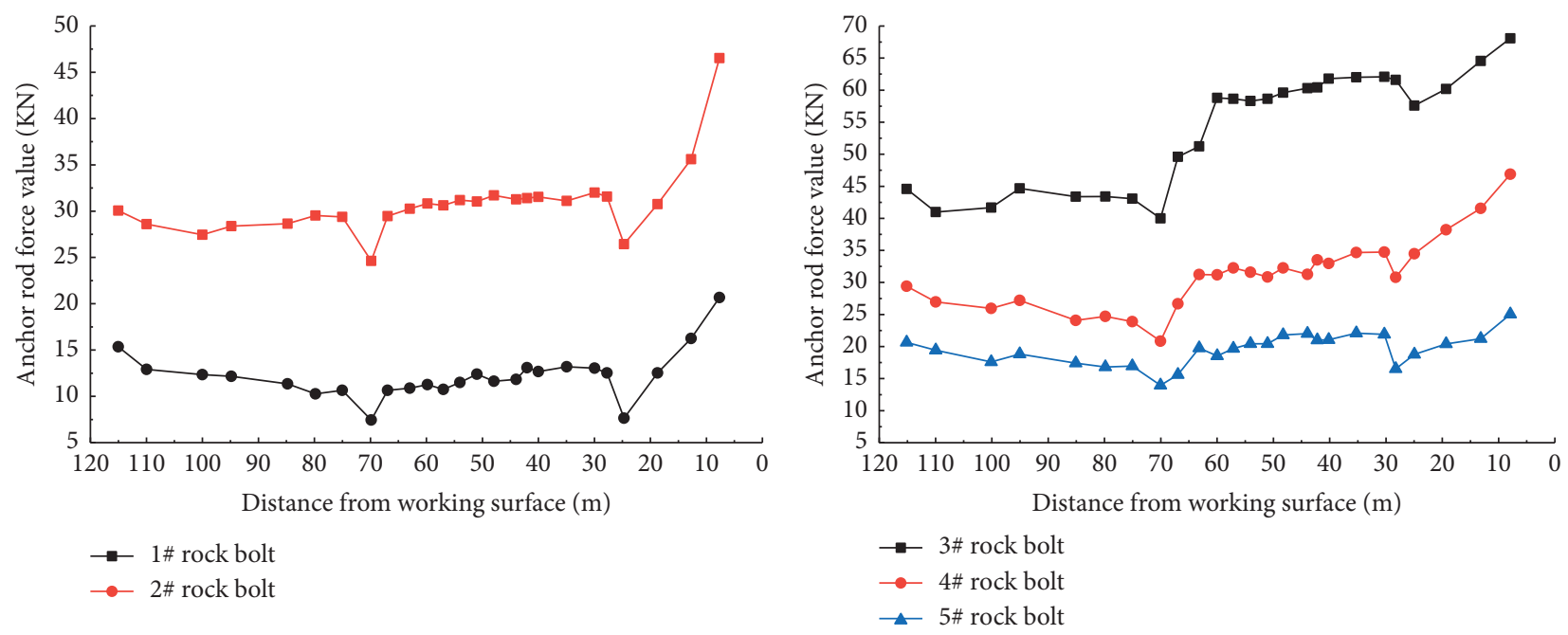

(a)

(b)

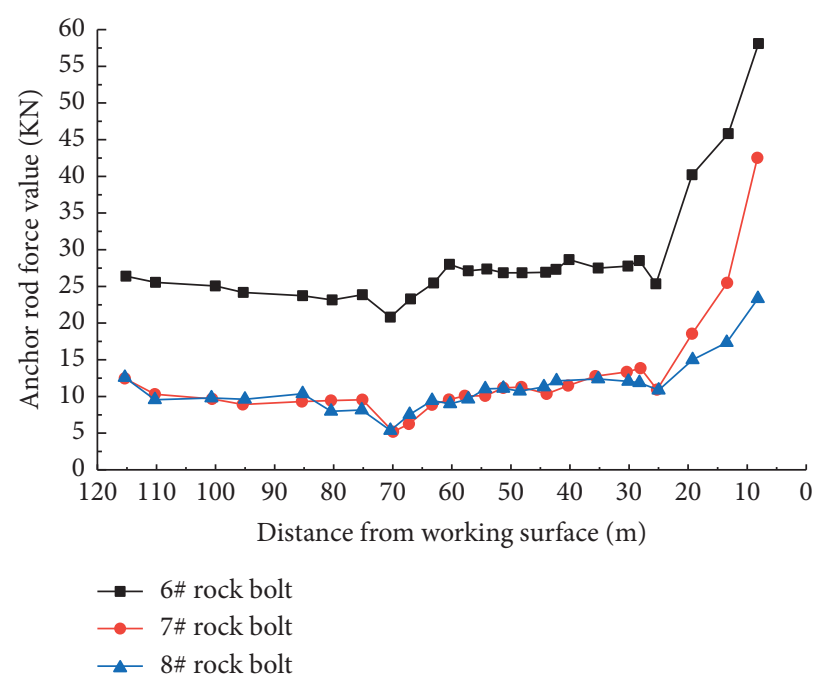

(c)

Figure 11: Stress characteristics of bolts in air-return roadway 5103. (a) Pillar side. (b) Roof. (c) Panel. 


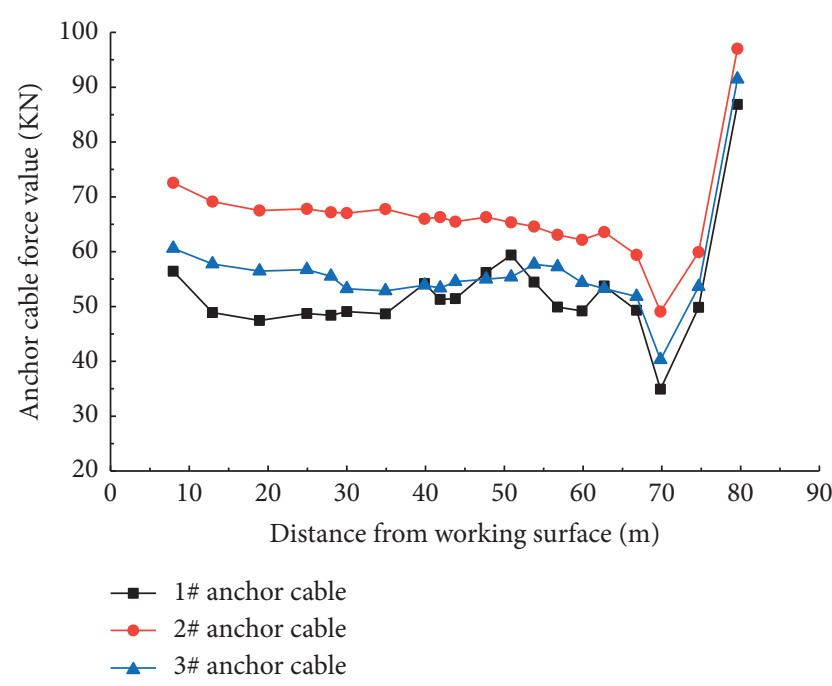

FIgURE 12: Stress characteristics of roof anchored cable in airreturn roadway 5103 .

is the mining advance affected section, the roadway deformation begins to increase, and the anchor cables stress also increases.

(5) The stress of bolts and anchor cables are compared. The biggest difference is as follows: the stress of bolts decreases at $20 \mathrm{~m}$ away from the panel, while the stress of anchor cables is almost unchanged. This is because the advance hydraulic prop within $20 \mathrm{~m}$ has a certain supporting effect on the surrounding rock, resulting in the smaller failure depth of the surrounding rock. The anchorage depth of bolts is shallower, and the anchorage depth of bolts is more affected by the stress change of the surrounding rock, while the anchorage depth of anchor cables is larger and the anchorage depth of bolts is less affected by the stress change of the surrounding rock.

(6) The bolt and anchor cables in the whole roadway are not broken. The results show that the supporting technology of high-strength and high prestress bolt + short anchor cables can effectively control the deformation of the surrounding rock of the roadway, and the underground application has achieved good results.

5.2. Analysis of the Roadway Surface Displacement. Figure 13 shows the deformation curve of the roadway roof and two sides. The specific analysis is as follows.

Generally, the increased displacement of the roadway roof, floor, and two sides is consistent, and the unit displacement keeps increasing. In the range of $80 \mathrm{~m}-115 \mathrm{~m}$ away from the panel, the roof and two sides of the roadway are not affected by the mining of the panel and are relatively stable, and the displacement is almost zero. Within the range of $40 \mathrm{~m}-80 \mathrm{~m}$ from the panel, the displacement of the roof and side of the roadway increases rapidly, but the change value is very small (below $6 \mathrm{~mm}$ ). The displacement of the roof is relatively small compared with the side, and the side is

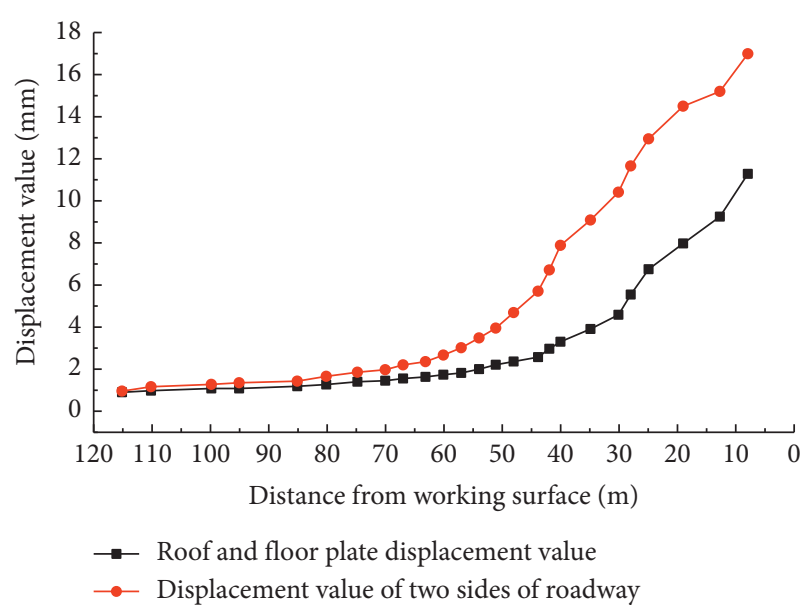

FIGURE 13: Variation curve of the surrounding rock displacement of in air-return roadway 5103.

more sensitive to mining. When the distance from the panel is $40 \mathrm{~m}$ or less, the displacement of the roof, floor, and two sides increases rapidly, and the increase rate is about 2 times compared with that in the range of $40 \mathrm{~m}-80 \mathrm{~m}$ from the panel. It shows that this section is greatly affected by the mining of the panel, but the final displacement is less than $18 \mathrm{~mm}$, which far meets the production requirements. Therefore, the high-strength and high prestressed anchor cables supporting technology can significantly control the deformation of the surrounding rock of the roadway.

\section{Conclusions}

(1) After mining the adjacent panel in Wangcun coal mine, the vertical stress around the surrounding rock of air-return roadway 5103 increases by $170.1 \%$ compared with that in the excavation stage, and the maximum roof subsidence increases by $194.5 \%$ compared with that in the original excavation. Therefore, the dynamic pressure has a significant impact.

(2) The supporting technology of high prestressed bolt and short anchor cables is put forward, the reasonable range of short anchor cables is determined, and the surrounding rock control scheme of airreturn roadway 5103 is obtained.

(3) The field monitoring results show that the bolt stress is divided into 4 stages, including the loss stage of prestress, the sudden-decrease stage of the roof periodic weighting, the decrease stage of advanced support, and the rapid-increase stage of strong disturbance. The stress of bolts and anchor cables is compared. The biggest difference is that the stress of bolts decreases at $20 \mathrm{~m}$ away from the panel, while the stress of anchor cables is almost unchanged.

(4) The closer the distance from the panel, the greater the displacement of the roadway roof and floor and two sides, and the higher the growth rate. However, the final displacement of the roof, floor, and two sides is within $18 \mathrm{~mm}$, and the bolt and anchor cables 
are not broken. It shows that the supporting technology of high-strength and high prestressed anchor cables can significantly control the deformation of the surrounding rock of the roadway.

\section{Data Availability}

The data used to support the findings of this study are included within the article.

\section{Conflicts of Interest}

The authors declare that they have no conflicts of interest regarding the publication of this paper.

\section{Acknowledgments}

This work was supported by the National Natural Science Foundation of China (U1904128, 51774110, and 51704095) and Program for Science \& Technology Innovation Talents in Universities of Henan Province (19HASTIT047).

\section{References}

[1] F. Du, W. Q. Wang, Z. H. Li, and F. Q. Gong, "Study on the evolution law of fracture field in full-mechanized caving mining of double system and extrathick coal seam," Advances in Civil Engineering, vol. 2020, Article ID 8880526, 12 pages, 2020.

[2] L. Zhe and G. Q. Cai, "Study on the mechanical behavior of double primary support of soft rock tunnel under high ground stresses and large deformation," Advances in Civil Engineering, vol. 2020, Article ID 8832797, 9 pages, 2020.

[3] D. Ma, J. Wang, X. Cai et al., "Effects of height/diameter ratio on failure and damage properties of granite under coupled bending and splitting deformation," Engineering Fracture Mechanics, vol. 220, Article ID 106640, 2019.

[4] X. L. Cao, W. M. Gong, F. X. Zhou, and G. L. Dai, "Stress analytical solution for shallow buried lined circular tunnel under the deformation of surrounding rock inner edge," Geotechnical and Geological Engineering, vol. 37, no. 5, 2019.

[5] F. X. Xie, F. L. He, S. F. Yin, Z. Wu, and G. Zhang, "Study on asymmetric control of large section gob-side coal entry influenced by strong mining," Journal of Mining and Safety Engineering, vol. 33, no. 6, pp. 999-1006, 2016.

[6] Y. C. Zhao, D. F. Lu, and Y. Chen, "Research to the influence of bolt direction on the surrounding rock," Applied Mechanics and Materials, vol. 353-356, pp. 1749-1752, 2013.

[7] W. S. Shen, "The study on tunnel surrounding rock displacement prediction," Applied Mechanics and Materials, vol. 340, p. 2488, 2013.

[8] B. X. Huang, N. Zhang, H. W. Jing et al., "Large deformation theory of rheology and structural instability of the surrounding rock in deep mining roadway," Journal of China Coal Society, vol. 45, no. 3, pp. 911-926, 2020.

[9] D. Ma, H. Duan, W. Liu, X. Ma, and M. Tao, "Water-sediment two-phase flow inrush hazard in rock fractures of overburden strata during coal mining," Mine Water and the Environment, vol. 39, no. 2, pp. 308-319, 2020.

[10] P. F. Jiang, S. F. Dai, J. R. Liu et al., "Evolution of the comprehensive stress field and supporting measures for the roadway surrounding rock affected by strong mining in the deep and ultra-thick coal-seam," Coal Mining Technology, vol. 20, no. 6, pp. 60-66, 2015.

[11] P. F. Jiang, "Research on evolution of integrated stress field of surrounding rock of mining while digging opposite roadway in deep and ultra-thick coal seam," Coal Science and Technology, vol. 48, no. 8, pp. 26-36, 2020.

[12] L. L. Guo, D. W. Zhou, D. M. Zhang et al., "Deformation and failure law of surrounding rock in the roadway under mining influence," Journal of Mining and Strata Control Engineering, vol. 3, 2021.

[13] H. S. Jia, K. Pan, S. W. Liu et al., "The deformation and failure mechanism and control technology of mining influenced roadway sides," Journal of Mining and Safety Engineering, vol. 37, no. 4 , pp. 689-697, 2020.

[14] J. H. Sheng, G. H. Li, L. Y. Wang et al., "Characteristics of stress-field environment and roof falling mechanism of mining influenced roadway," Journal of Mining and Safety Engineering, vol. 34, no. 4, pp. 707-714, 2017.

[15] Y. M. Qi, X. E. Zhao, H. B. Bai, and Y. Jiao, "Deformation simulation of surrounding rock at faulted zone during roadway drivage," Advanced Materials Research, vol. 361-363, p. 1480, 2012.

[16] N. Gao, X. M. Cui, and C. Y. Gao, "Novel high-precision grey forecasting model and its application of deformation of tunnel surrounding rock," Applied Mechanics and Materials, vol. 90-93, p. 1446, 2011.

[17] D. Ma, H. Duan, Q. Zhang et al., "A numerical gas fracturing model of coupled thermal, flowing and mechanical effects," Computers, Materials \& Continua, vol. 65, no. 3, pp. 21232141, 2020.

[18] S. Y. Sun, C. Z. Zhao, Y. Zhang et al., "The deformation characteristics of surrounding rock of crossing roadway in multiple seams under repeated mining and its repair and reinforcement technology," Journal of Mining and Safety Engineering, vol. 37, no. 4, pp. 681-688, 2020.

[19] Y. D. Qiao, Z. P. Meng, S. Zhu et al., "Study on coal pillar failure mechanism and surrounding rock control technology under influence of secondary mining," Coal Science and Technology, vol. 48, no. 6, pp. 71-77, 2020.

[20] C. Li, T. H. Huo, Z. Wu et al., "Mechanism and stability control of nonuniform and violent deformation of dynamic pressure roadway roof," Journal of Central South University (Science and Technology), vol. 51, no. 5, pp. 1317-1327, 2020.

[21] K. Lu, Z. G. Deng, J. C. Feng et al., "Surrounding rock failure mechanism of reserved roadway under superimposed mining and its control technology," Journal of Mining and Safety Engineering, vol. 36, no. 4, pp. 685-769, 2019.

[22] D. Ma, H. Duan, X. Li, Z. Li, Z. Zhou, and T. Li, "Effects of seepage-induced erosion on nonlinear hydraulic properties of broken red sandstones," Tunnelling and Underground Space Technology, vol. 91, Article ID 102993, 2019.

[23] X. Y. Wu, H. T. Liu, J. W. Li et al., "Temporal and spatial evolution law and stability control of plastic zone in repeated mining roadway," Journal of China Coal Society, vol. 45, 2020.

[24] C. Wang and X. Q. Pi, "A study on the influence by Karst on the stability of surrounding rock in neighborhood tunnel," Advanced Materials Research, vol. 446-449, p. 1615, 2012.

[25] B. Z. Yao, "Influence analysis of anchor parameters on stability of surrounding rock of roadway with rock burst hazard," Advanced Materials Research, vol. 368-373, p. 1494, 2012.

[26] D. Ma, H. Duan, J. Liu, X. Li, and Z. Zhou, "The role of gangue on the mitigation of mining-induced hazards and environmental pollution: an experimental investigation," Science of the Total Environment, vol. 664, pp. 436-448, 2019. 
[27] Q. Y. Xu, Q. G. Huang, G. C. Zhang et al., "Fracture and instability mechanism and control technology of a narrow coal pillar in an entry in fully mechanized caving mining under intense effect mining," Journal of Mining and Safety Engineering, vol. 36, no. 5, pp. 941-948, 2019.

[28] Y. W. Lan, H. Yan, P. F. Xing et al., "Study on cables in roof controlling system to support the intensively dynamic pressure roadway in extra-thick coal seam," Journal of Mining and Safety Engineering, vol. 35, no. 2, pp. 2765-3282, 2018.

[29] Q. Feng, B. S. Jiang, Q. Zhang, and L. P. Wang, "Analytical elasto-plastic solution for stress and deformation of surrounding rock in cold region tunnels," Cold Regions Science and Technology, vol. 108, 2014.

[30] Y. X. Li, "Analysis of surrounding rock deformation based on M-C model and cvisc model," Applied Mechanics and Materials, vol. 295-298, p. 2301, 2013.

[31] Z. Q. Han, J. Liu, K. Bian, and Q. Chen, "Research on geological characteristics and deformation law of surrounding rock of a tunnel with carbonaceous schist in Northwest Hubei Province," Applied Mechanics and Materials, vol. 256-259, p. 2156, 2013.

[32] Y. L. Xu, M. T. Xu, L. X. Cheng et al., "Control mechanism and experimental study on renewable bearing arch in soft and mudding roadway under dynamical pressure impact," Journal of Mining and Safety Engineering, vol. 35, no. 6, pp. 1135-1141, 2018.

[33] L. J. Ding and Y. H. Liu, "Study on deformation law of surrounding rock of super long and deep buried sandstone tunnel," Geomechanics and Engineering, vol. 16, no. 1, 2018.

[34] D. Ma, J. Zhang, H. Duan et al., "Reutilization of gangue wastes in underground backfilling mining: overburden aquifer protection," Chemosphere, vol. 264, no. 1, Article ID 128400, 2021.

[35] Z. G. Tao, F. Zhao, H. J. Wang, H. J. Zhang, and Y. Y. Peng, "Innovative constant resistance large deformation bolt for rock support in high stressed rock mass," Arabian Journal of Geosciences, vol. 10, no. 15, 2017.

[36] F. H. Ma, Y. Wang, and Z. B. Wang, "Influence of sidepressure coefficient on deformation of tunnel surrounding rock and bolt axial force," Applied Mechanics and Materials, vol. 741, p. 3844, 2015.

[37] N. Zhang, L. Yuan, C. L. Han, J. H. Xue, and J. G. Kan, "Stability and deformation of surrounding rock in pillarless gob-side entry retaining," Safety Science, vol. 50, no. 4, 2012. 